\title{
Putting the World Back into World Cinema
}

\author{
Tiago de Luca \\ University of Warwick, Coventry, UK \\ T.de-Luca@warwick.ac.uk
}

\begin{abstract}
The world envisioned by the idea of world cinema is often tied to a conception of the planet in terms of the global circulation of films and networks of production, consumption and distribution. This article argues for the need to confront the world as a representational and aesthetic category in and of itself.
\end{abstract}

\section{Keywords}

world cinema - transnationalism - global cinema - earth - world - totality universalism

The political in our time must start from the imperative to reconstruct the world in common.

ACHILLE MBEMBE

The world envisioned by the idea of world cinema is often tied to a conception of the planet in terms of the global circulation of films and networks of production, consumption and distribution. Though this conception has been important and useful in unpacking the circuits and structures of transnationalism upon which cinema has relied past and present, I would argue it has also contributed, in film studies, to an obfuscation of the world as a representational and aesthetic category in and of itself. This is surprising considering that 
figurations of world and earth have proliferated in a number of trends, genres and modes in cinema over the last two decades. Part of this resistance to wholeworld narratives and imaginings may be connected with the suspicion in the humanities often annexed to the categories of universality and totality. Yet I believe it is time that we confront and deconstruct this suspicion, especially as the current environmental collapse urgently asks for planetary thinking.

Before it became a popular sub-discipline in film studies, world cinema was already a commercial label that partitioned the world in two, with the qualifier world attached to cinema, as with the corresponding 'world music' and 'world literature', often denoting non-Western or, more specifically, non-Hollywood filmmaking. Against this clear-cut division in their collection Remapping World Cinema: Identity, Culture and Politics in Film (2006), Song Hwee Lim and Stephanie Dennison proposed a formulation of world cinema 'not in terms of "the West vs. the Rest" but in relation to notions such as hybridity, transculturation, border crossing, transnationalism and translation' (2006:6). In her article 'Towards a positive definition of World Cinema' featured in the same volume, Lúcia Nagib noted the negative and restrictive definition of world cinema in traditional film histories as a cinema that must be appraised either in relation or as a resistance to Hollywood. By rejecting binarism, Nagib proposed a polycentric understanding of world cinema that includes Hollywood as one cinematic player among others. She wrote: 'World cinema is simply the cinema of the world. It has no centre. It is not the other, but it is us. It has not beginning and no end, but is a global process. World cinema, as the world itself, is circulation' (2006:35).

Nagib's emphasis on process and circulation would resonate with understandings of the global as the stage on which institutional, industrial and aesthetic frameworks coalesce, enabling films to travel worldwide and connect with other audiences. In their anthology Global Art Cinema: New Theories and Histories (2010), Rosalind Galt and Karl Schoonover thus posited the notion of art cinema as 'best placed to engage pressing contemporary questions of globalization, world culture, and how the economics of cinema's transnational flows might intersect with trajectories of film form' (2010:3). More recently, Elena Gorfinkel has updated the idea of flows with that of 'networks' in 'emergent media technologies and processes of globalization' (2018:8). Following Nagib, Gorfinkel notes that a focus on circulation 'is novel and urgent not only because it harnesses the necessary element of movement so central to cinema's formal substrate but because it recalibrates cinema's worldliness as a function of its capacity to move' (2018:8, emphasis in the original).

It is hard to overestimate the importance of these arguments for the establishment and development of world/global cinema as a more encompassing, 
wide-ranging and pluralistic theoretical concept, discipline and methodology. Yet by and large these studies also substantiate a concern raised by W. J. T. Mitchell already in 2007, when he noted that 'the general tendency has been to talk about the global distribution of images, their circulation in forms of mass media such as cinema, television, advertising, and the internet' rather than about 'images of the world and the global as such' (2007:50). Mitchell proposed: 'We need to begin, then, by asking ourselves: How do we imagine, depict or know the global?' (2007:50). Significantly, one of the first articles to engage with the problematics of world cinema in film studies had already attempted to provide a reply to this question. In his 1998 essay 'Baraka: World Cinema and the Global Culture Industry', Martin Roberts called attention to 'the increasing number of films since 1960 which are in different ways about something called "the world" itself', including 'Chris Marker's Sans Soleil (1982), Godfrey Reggio's Powaqqatsi (USA, 1988), Wim Wender's Until the End of the World (Germany/France/Australia, 1991), Jim Jarmusch's Night on Earth (USA, 1991), or even the IMAX film Blue Planet (USA, 1990)' (1998:77). While alerting to the 'imperialist nostalgia' underpinning some of these films, as in Baraka (USA, 1992), Roberts's conclusion that 'studies of "global" or "world" cinema ... have tended to focus primarily on transnational or local film practices ... rather than on the global as such' would prove true in the years to come (1998:77).

One reason why this has been the case, as Roberts suggests, 'may simply be a suspicion of the global itself', given that 'globalizing discourses, with their claims to speak for everyone, [are seen] as monolithic and hegemonic' (1998:77). In his Apollo's Eye: A Cartographic Genealogy of the Earth in the Western Imagination, Denis Cosgrove is emphatic: current 'one-world' and 'whole-earth' discourses are informed by a 'liberal mission of universal redemption [that] is inescapably ethnocentric and imperial' (2001:265). Meanwhile, as Fredric Jameson notes, 'the doxa ... of the current moment' can be 'summed up in the conviction that universals are inevitably normative, and thereby oppressive and binding on individuals and minorities' (2015:126-7). There is no denying of the troubling legacies of Enlightenment universalism and the insidiousness of global capitalism in their adherence to ideologies of imperialism, expansionism and domination. In fact, this is one of the reasons why it is urgent to examine the global imaginaries of today, not least because, since Roberts's essay, they have exploded in number and popularity, appearing in the guise of global network narratives (Babel, 2006; 36o, 2011; Mammoth 2009), collaborative global documentaries (One Day on Earth, 2012; Life in a Day, 2012) and TV series and documentaries concerned 
with the future of the planet (ввс Planet Earth II, UK, 2016; Home, Yann Arthus-Bertrand, France, 2009). ${ }^{1}$

Some of these titles have justifiably been put to the task for their activation of an imperial optics that homogenises the world. ${ }^{2}$ Yet are figures of world totality and community inherently bad? Can some of the works mentioned above be read as complex, sometimes contradictory expressions of globalism rather than simply as the univocal vessels of imperial ideology? It seems to me that Jay Winter and Janine Marchessault have advanced our understanding of world making by drawing attention to the utopian energies that can underpin the global in audiovisual media, from Albert Kahn's monumental Archives de la Planète (Winter 2006) through to postwar moving-image experiments (Marchessault 2017). For them, utopian projects of global scope and ambition have often been spurred on by the threat of total annihilation posed by world wars, even if such projects are never without contradictions and can often mask or encapsulate 'a particular ideology, the interests and outlook of discrete social and political formations' (Winter 2006:206).

Today, the threat of human annihilation is posed not so much by total war but by the environmental breakdown, which dramatically requires solutions on a global scale and a Humboldtian conception of the planet as a whole made up of intricately interdependent lifeworlds (see Walls 2009; Wulf 2014). In this context, there is no shortage of films that have confronted head-on the global while remaining critical of its associations with the all-encompassing circuits of capital. Natalie Bookchin's multichannel installations, for example, which often make their way to the web as videos on YouTube, are not only composed of amateur videos she sources from the Internet, but are themselves critical reflections on the world of images instantiated by the World Wide Web. These include Round the World (USA, 2007), where images from security webcams are alternated with the verbal transcription of Thomas Edison's imagined 1888 round-the-world trip, as well as trip (USA, 2008), in which amateur images of travels from 70 different countries filmed from window cars are stitched together with the aim of creating a global trip documented by missionaries, truckers, soldiers and migrants. The oeuvre of the Austrian filmmaker Nikolaus Geyrhalter is also replete with attempts to confront the world as a totality while interrogating the exclusionary forces of globalisation and the destruction of the earth wrought upon by capitalism. Examples include his Elsewhere (Austria, 2001), which takes the turn of the millennium as the starting point for a trip encompassing twelve countries with the aim of registering

1 I have elsewhere expanded on these trends and genres. See De Luca (2017) and De Luca (2018).

2 See, for example, Druick (2019) and Druick (2018). 
the disappearance of local cultures, and more recently, Earth (Austria, 2019), which delves deep into extractive activities around the globe by treating the world as both planet and soil. Films as disparate as the experimental Medium Earth (the Otolith Group, UK, 2013), The Human Surge (Eduardo Williams, Portugal/Argentina/Brazil, 2016), Human Flow (Ai Weiwei, Germany, 2017) and Walden (Daniel Zimmerman, Austria/Switzerland, 2018), to cite a few more, equally provide illuminating takes on globalisation and/or the planetary in times of turbulent migratory, ecological and geological crises.

To varying extents, these films affirm the existence of a deeply interconnected world that includes both the human and the nonhuman while never succumbing to a glossy and homogenising discourse of globality. They likewise foster political, social and ecological thinking while eschewing a myopic localism and pointing to the necessity of a visualisation of the planet as a singular whole that necessitates attention and care for the future. At a time when 'decolonisation' has emerged as an important project in the humanities, I would therefore concur with Achile Mbembe's recent assertion that insofar as 'colonial expansion was a planetary project', decolonisation must be by definition 'a planetary enterprise, a radical openness of and to the world, a deep breathing for the world as opposed to insulation' (Torbjørn 2018). Perhaps the time has come, then, for world cinema to open itself to the world.

\section{References}

Cosgrove, D. (2001). Apollo's Eye: A Cartographic Genealogy of the Earth in the Western Imagination. Baltimore, Maryland: The John Hopkins University Press.

De Luca, T. (Spring 2017). Figuring a Global Humanity: Cinematic Universalism and the Multinarrative Film. Screen, 58:1, pp. 18-37.

De Luca, T. (Autumn 2018). Earth Networks: The Human Surge and Cognitive Mapping. NECSUS: European Journal of Media Studies, https://necsus-ejms.org/ earth-networks-the-human-surge-and-cognitive-mapping/.

Dennison, S. and Lim, S. H. (2006). Introduction: Situating World Cinema as a Theoretical Problem. In: Dennison S. and Lim S. H. eds., Remapping World Cinema: Identity, Culture and Politics in Film. London and New York: Wallflower Press, pp. 1-15.

Druick, Z. (2018). A Wide-Angle View of Fragile Earth: Capitalist Aesthetics in the Work of Yann Arthus-Bertrand. Open Cultural Studies, pp. 396-405.

Druick, Z. (October 2019). Environmentalism from the Sky? Docalogue (online), available at https://docalogue.com/october-anthropocene-the-human-epoch/; and (2018). A Wide-Angle View of Fragile Earth: Capitalist Aesthetics in the Work of Yann Arthus-Bertrand, Open Cultural Studies, pp. 396-405. 
Galt, R. and Schoonover, K. (2010). Introduction: The Impurity of Art Cinema. In: Galt, R. and Schoonover, K. eds., Global Art Cinema: New Theories and Histories. New York: Oxford University Press, pp. 3-27.

Gorfinkel, E. (2018). Global Cinemas in a Time of Networks. In: Gorfinkel, E. and Williams, T. eds., Global Cinema Networks. New Brunswick, Camden, and Newark, New Jersey and London: Rutgers University Press, pp. 6-20.

Jameson, F. (2015). The Aesthetics of Singularity, New Left Review, 92, pp. 101-132.

Marchessault, J. (2017). Ecstatic Worlds: Media, Utopia, Ecologies. Cambridge, MA and London: MIT Press.

Mitchell, W. J. T. (2007). World Pictures: Globalization and Visual Culture. Neohelicon, 34:2, pp. 49-59; 5 .

Nagib, L. (2006). Towards a Positive Definition of World Cinema. In: Dennison, S. and Lim, S. H. eds., Remapping World Cinema: Identity, Culture and Politics in Film. London: Wallflower, pp. 30-37.

Roberts, M. (1998). Baraka: World Cinema and the Global Culture Industry. Cinema Journal, 37:3, pp. 62-82.

Tumyr Nilsen, T. (30 November 2018). Thoughts on the Planetary: An Interview with Achille Mbembe. New Frame (online), https://www.newframe.com/thoughts-onthe-planetary-an-interview-with-achille-mbembe/ (accessed 20 November 2019).

Walls, L. D. (2009). The Passage to Cosmos: Alexander von Humboldt and the Shaping of America. Chicago and London: University of Chicago Press.

Winter, J. (2006). Dreams of Peace and Freedom: Utopian Moments in the $20^{\text {th }}$ Century. New Haven and London: Yale University Press.

Wulf, A. (2014). The Invention of Nature: The Adventures of Alexander von Humboldt, the Lost Hero of Science. London: John Murray. 